\title{
International Trade in Services and the Evolving Position of Developing Countries
}

\author{
Alberto Gabriele \\ UNCTAD, Geneva
}

\begin{abstract}
This paper illustrates the main trends in international trade in services during the last two decades of the last century, focusing particularly on developing and transition countries. The Introduction briefly exposes some of the shortcomings and methodological problems affecting statistics on international trade in services, and explains why BOP data, albeit inadequate, are the only source available so far to carry out a comprehensive comparative and historical analysis in this domain. Section 2 describes basic trade trends for each of the 10 services sectors, identifies the major exporters of services among developing and transition countries and analyzes the evolution of their relative position in international trade in services. It shows that most of them are either large semi-industrialized Asian countries or European transition countries. Yet, there are also cases of other developing countries exhibiting a strong tendency towards specializing in one or few specific services sub-sectors. Section 3 examines global trade trends for services as a whole. They show that services exports have been the most dynamic component of world trade and the world market share of developing countries has been on the rise. However, a generalized deceleration in the expansion of world trade in services occurred in the late 1990s. The growth rate of services exports from developing countries slowed down, and their ability to import services also declined, with a negative impact on their development prospects. In the Conclusions, a tentative explanation for the aforementioned results is proposed. Most export-oriented services activities in developing countries are concentrated in traditional services sectors. They are also poorly integrated to the rest of the domestic economy. Thus, their potential as engines for growth is relatively weak. The weight of these
\end{abstract}

\footnotetext{
*Corresponding address: Alberto Gabriele, UNCTAD, Room8023, Paris des Nations, 1211 Geveva 10, Tel: (+)00-41-22-917 5569, E-mail: alberto.gabriele@unctad.org (C)2004-Center for International Economics, Sejong Institution, All Rights Reserved.
} 
structural weaknesses was magnified by an economic policy bias. Under conditions of financial stress, many previously inward-oriented developing countries felt compelled to divert resources towards exports as if they were a goal per se, rather than a component of a comprehensive long-term growth-maximizing strategy. In the services sector as well, imports were sacrificed and exports intensely encouraged. As liberalizing reforms aimed at accelerating developing countries' trade and financial integration in the world economy were often carried out in an unbalanced and hasty fashion, their results turned out being less than fully satisfactory.

- JEL Classification: 014, F02, F13

- Keywords: Services, Trade Policy, International Trade, Trade Liberalization, Developing Countries, GATS, Export-Led Growth, Globalizaton

\section{Introduction}

Comprehensive statistical studies on the role of developing countries in international trade in services are scarce. A recent broad evaluation - based largely on US services import data - is presented in Langhammer (2002). However, I am aware of only one systematic statistical exercise on the evolution of international trade in services based on the IMF BOP database, which was carried out by the WTO Secretariat (WTO 2000). However, this paper differs from WTO 2000 in two fundamental aspects: its perspective is a long term one (from 1980 to 2000) and it focuses mainly on developing and transition countries.

Presently-available official statistics on international trade in services are far from being exhaustive and comprehensive, and in the case of developing and transition countries, this type of information is even more limited. Bearing this in mind, one must operate with a certain dose of caution when interpreting the economic meaning of the data presented and discussed below. The main reasons for this statistical inadequacy are two, and both related to the peculiar nature of services as tradable economic activities and to the relative novelty of multilateral attempts to evaluate and regulate international trade in this domain. The first, and most important, is that the GATS typology based on four modes of supply is so far not matched by existing statistics (see WTO 1997, part II), especially with respect to mode 3 (commercial presence). As a result, most statistics on trade in services fail to capture local sales of services by foreign firms, and do not make a distinction between exports of services carried out by nationals and those carried out by foreign enterprises. The other reason stems from a divergence in 
classification criteria between existing statistics on trade in services and the GATS commitments (most of which are based on the GNS classification ${ }^{1}$ ).

The only comprehensive and consistent data source on international trade in services is constituted by the IMF Balance of Payments (BOP) statistics. More detailed sectoral statistics are available for most services sectors, but they are collected with sector-specific criteria and they are not mutually comparable in a systematic fashion. Both BOP and sectoral statistics suffer from the drawbacks outlined above. Data on trade in services carried out abroad by foreign affiliates of transnational corporations are only available (for some services sectors) for the United States. This is the only country that reports these statistics on Foreign Affiliates Trade (FAT) on a regular basis. Statistical coverage on trade in services is improving, and the Inter-Agency Task Force on Trade in Services Statistics is developing a common manual that will represent a significant step forward in the strive to improve coverage and accuracy of services statistics. However, statistical reporting on trade in services is not likely to match the breadth and precision of statistics on merchandise trade in the foreseeable future. This is due, among other things, to methodological problems, a major one being the difficulty in distinguishing between price and volume data in services production and $\operatorname{trade}^{2}$ (see WTO 2000, para V).

This paper utilizes as a source BOP data made available on-line by WTO and UNCTAD $^{3}$. These data, in spite of their shortcomings, are consistent and internationally comparable, and can also usefully be related with other basic macroeconomic statistics such as total GNP, total exports, and the like. Besides data on trade in total services, BOP data on trade in services by sector are also available, and will be utilized in some of the tables presented and commented below ${ }^{4}$.

${ }^{1}$ The GNS classification is largely based on the UN-CPC classification, but deviates from the latter in telecommunication, financial, and transport services.

${ }^{2}$ It is more difficult than in the case of merchandise trade to determine to what extent an increase in trade for a particular services sector is due, respectively, to: changing in relative prices; diverging variations in the exchange rate and in inflation among trading partners; improvements in product quality; changes infra-sectoral product composition; "true" quantitative increases in trade volumes( WTO 2000, p.17).

${ }^{3}$ Most BOP statistics on trade in services were reported according to the concepts and the classification system of the $4^{\text {th }}$ edition (1977) of the IMF Balance of Payments Manual (BPM-4). A transition is now occurring to the conceptual framework and the criteria of the $5^{\text {th }}$ edition of the manual (BPM-5). With respect to BPM-4, BPM-5 is more disaggregated and relatively less discordant with respect to GNS.

${ }^{4} \mathrm{BOP}$ data on trade in services by sector are not directly comparable to other sector-specific, such as the International Civil Aviation Organization (ICAO) for air transport, the International Telecommunication Union (ITU) for telecommunications, and the like. 
Sectoral trade data refer to 10 services sectors (transport; travel; communications; construction; computer and information services; financial and insurance services; other business services; royalties and license fees; personal, cultural and recreational services; government services). Most IMF members report aggregate trade statistics for transportation, travel, insurance ${ }^{5}$, and other business services, but fewer report data for the other services sectors.

\section{Trade in 10 Services Sectors and the Role of Major Developing and Transition Countries Exporters}

Tables 1-10 refer to the 10 services sectors. Each one refers to one of the ten main services sectors (according to the BOP classification), and is composed by four parts. As some transition countries are among the major non-developed exporters in various services sectors, I deemed it necessary not to exclude them from the sectoral analysis, as I did for the sake of simplicity and consistency in the general analysis presented in Section 2. Part a presents export data for the world total and for a very large aggregate (DNC,TNC) constituted by all non-developed countries (i.e., developing and transition countries) ${ }^{6}$. Part b presents the same set of data for the major exporters (of services of each particular sector) among developing and transition countries. Part $\mathrm{c}$ and $\mathrm{d}$ show, for each of the abovementioned major exporters, the sector's share in total export of services and the country's share of world total exports respectively.

Table 1 presents data on exports of transport services, which, along with travel services, make up more than 50\% of world trade in commercial services ((WTO 2000, p.7). Their importance is indirectly reflected in the figures presented in Table 1c, which show that transport services' share of total exports of services is quite high for many of the major developing exporters (among them Korea, Kuwait, and Ukraine).

\footnotetext{
${ }^{5}$ As the aggregate sectoral classification for these services is "insurance and financial services", the corresponding data presented below should be considered with caution, as for many countries the insurance sub-component is likely to be better reflected in official BOP data than the financial services component.

${ }^{6} \mathrm{~A}$ number of caveats apply to the interpretation of Tables 2-11, and especially of part a. First, the DNC, TNC grouping is larger than the DNC grouping in Table 1, because it includes transition countries. Second, as the growth rates makes of many sectoral data on services exports are not yet available for the year 2000 for most developing countries, growth rates in table 2 refer to the periods 1980-1990, 1990-1999. Third, and most important, due to the aforementioned lack of comparable historical data for most transition countries, the meaning of the aggregate figures referring to the DNC,TNC grouping has to be seen as purely indicative.
} 
Several developing and transition countries are important exporters of transport services. Among transport services, those of most relevance, especially for developing countries, are maritime transport services ${ }^{7}$. In many countries, the strength of the commercial fleets stems from the competitiveness of the national shipbuilding industry, a mature but still quite relevant industrial sector. Actually, as can be seen from Table 1 (part b), most major exporters among non-developed countries are either European transition countries or relatively advanced semi-industrialized Asian and Latin

Table 1. Exports of Transport Services.

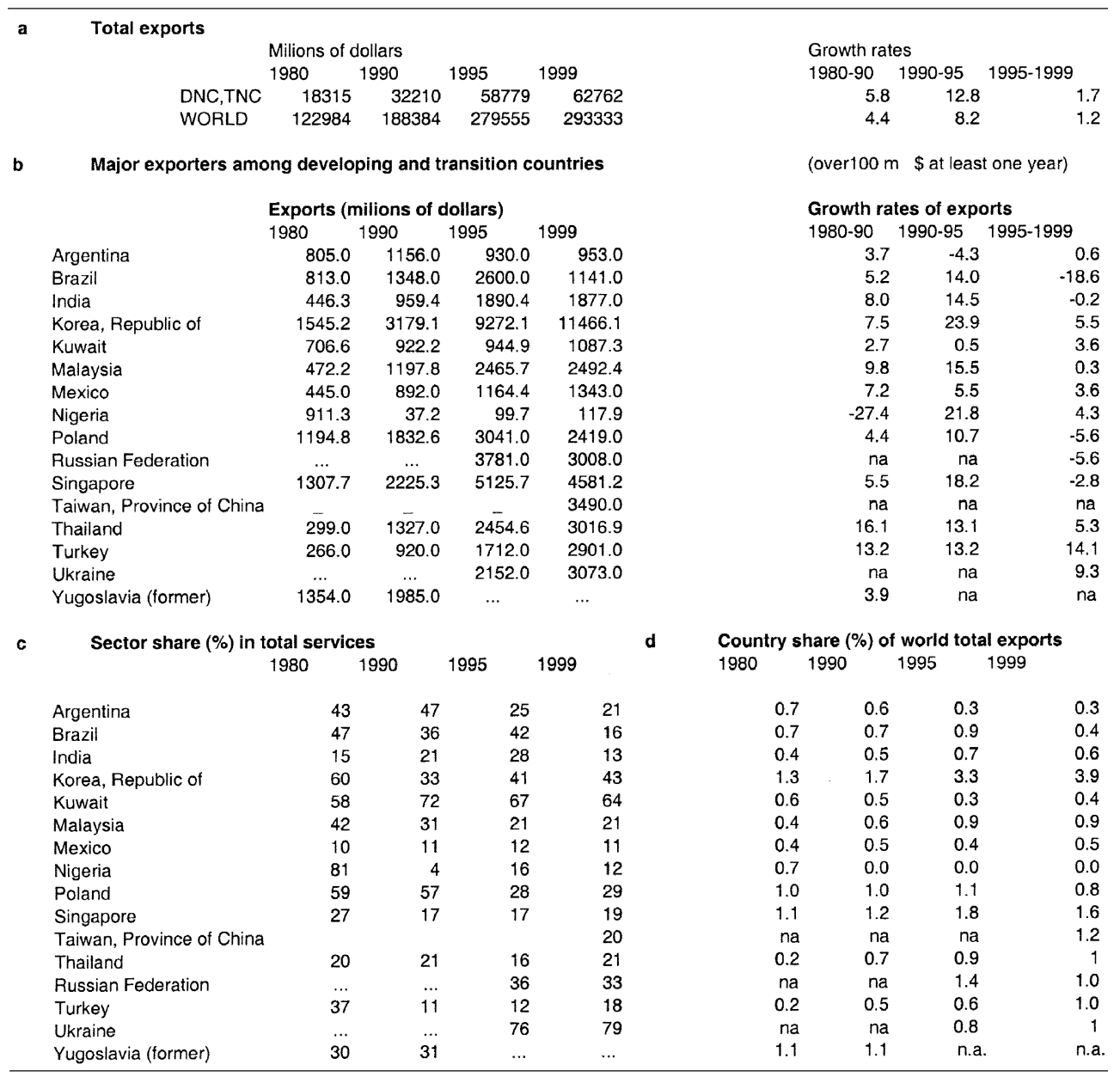

${ }^{7}$ Disaggregated data for maritime transport services are reported in the UNCTAD Review of Maritime Transport (WTO 1997, p. 12). 
American developing countries ${ }^{8}$. As opposed to the cases of other services sectors, it can be generally assumed that developing countries who enjoy a strong exporter position as transport services traders actually owE it mainly to the real international competitiveness of their national agents, rather than to the activities of foreign operators. Therefore, transport services exporters amongst developing and transition countries are likely to be in a position to reap most of the potential financial, technological, and economic benefits stemming from international trade.

The largest developing exporter of transport services is Korea, which experienced a very fast growth in exports over the whole period 1980-1999, but especially in the early 1990s. As a result, by the end of the decade Korea's exports of transportation services were over US\$ $11 \mathrm{bn}$, corresponding to an almost $4 \%$ share of the world market (Table1d). Other strong Asian exporters are Singapore, Taiwan, Thailand, Malaysia, Kuwait, and Turkey. ${ }^{9}$ Among transition countries, Russia, Poland, and Ukraine are major players, but their performance over the 1990s has been lackluster, reflecting persistent weaknesses in their reforming economies and their difficulties in re-positioning themselves in the international trade network. The largest Latin American economies (Argentina, Brazil, Mexico) are also among the major transport services exporters, but - due also to a weak performance during the most recent period - they do not match the strength of their Asian counterparts.

The economic significance for developing countries of another major services export sector, travel services, (see table 2), is usually quite different from to that of transport services. In most developing countries a large share of travel services exports receipts accrues directly or indirectly to foreign agents supplying the services and goods acquired by tourists and other travelers ${ }^{10}$, as well as the other inputs needed for the overall functioning of the service. The "leakage" effect tends to be more pronounced, the least developed and the more externally dependent the

\footnotetext{
${ }^{8}$ The main exceptions are constituted by Kuwait and Nigeria, whose presence among transport services exporters is due to their role as a major oil producer. With respect to the latter, in particular, Table A2b shows that - along with the other sectors of the country's economy - Nigeria's transport services trading activities collapsed in the 1980s, and subsequently underwent a modest recovery.

${ }^{9}$ India is also among the major developing exporters of transport services, but its role is relatively minor and appears to have has been declining in the late 1990s. With respect to China, its absence from the group of major developing exporters of transport services is due essentially to statistical inadequacies, taking into account the country's position in international trade (WTO 1997, p.13).

${ }^{10}$ Travel services exports receipts cover all the expenses of tourists and other travelers during their trips abroad (see WTO 1997, p.13).
} 
Table 2. Exports of Travel Services.

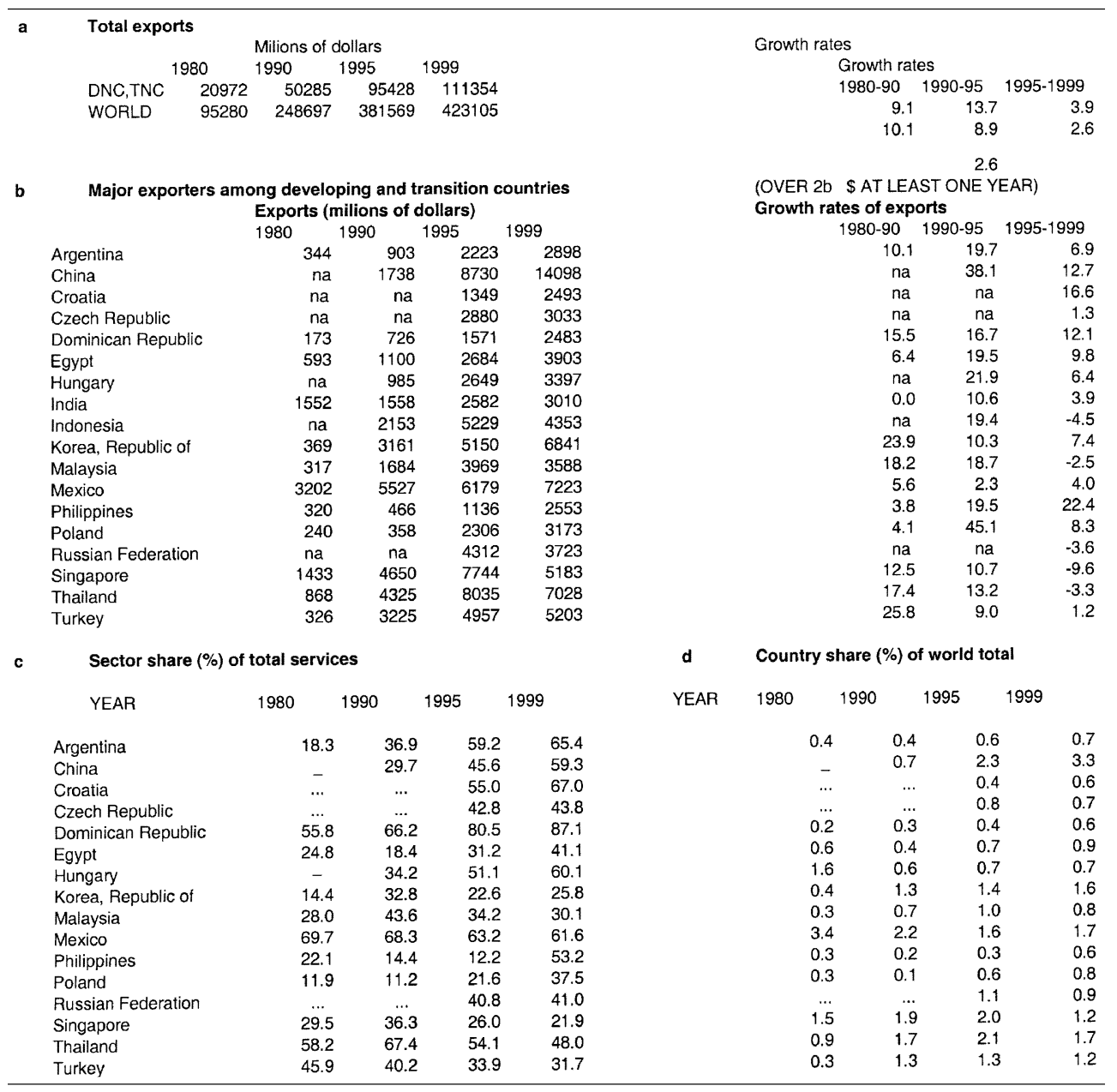

host country is, and the development impact of trade in travel services is consequently weaker. Taking into account this and other important caveats ${ }^{11}$, tourism has emerged in many developing countries as a powerful and fast-growing foreign exchange provider, and in several cases as the only vital non-traditional sector.

The largest exporter of travel services among developing countries is China (see table $2 b$ ), where the sector underwent an extraordinary fast growth during the

\footnotetext{
${ }^{11}$ The most relevant being the above-mentioned risk of depleting environmental and other non-renewable resources.
} 
1990s, leading in 1999 to export receipts of US\$ 14 bn, (the second highest yearly export receipt for any single services sector recorded in a developing country over the whole 1980-2000 period) .

China's share of the world market for (internationally traded) travel services in that year was 3.3\%, about twice as much as that of Korea and Mexico (Table 2d). The relevance of travel for the whole services component of China's economy is also underlined by its share of total exports of services (almost over 60\% in 1999), a figure higher than the correspondent one for any large semi-industrialized economy ${ }^{12}$ (Table 2c). Other large travel services exporters are Mexico ${ }^{13}$, Korea, Thailand, and Turkey, with more than US\$7bn in 1999 and/or 2000. The Philippines, a medium-sized player in this sector, recorded the highest growth rate among developing countries (22.4\%) in 1995-1999 (Table 2b).

Communication services ${ }^{14}$ are among the fastest growing traded services sectors, exhibiting double-digit growth rates of exports worldwide up to 1995 and a still quite respectable 5.8\% in the less dynamic 1995-1999 sub-period (Table 3). As opposed to the transport and travel services, which rely mostly on mature technologies, communication services are among the most high-technology intensive economic activities. On one hand, the very speed and the specific characteristics of the evolution of information technologies allow TNCs to exploit the cost advantages offered by the segmentation and de-localization of production processes. Yet, on the other hand, they also create market niches which can be captured by semi-independent operators in developing countries (see Teltscher 2002). ${ }^{15}$

Major exporters from developing and transition countries are not numerous, but some of them hold a non-negligible share of the world export market (Table 3d).

\footnotetext{
${ }^{12}$ Among major exporters, the relative share of travel services exports in total services exports in 1999 was also over or around 50\% in Argentina, Croatia, Hungary, Mexico, the Philippines, and Thailand. It is also very high in many smaller developing countries which rely mainly or exclusively on tourism as a provider of foreign exchange.

${ }^{13}$ Mexico, however, lost half of its world market share (which in 1980 was 3.4\%, the highest among nondeveloped countries)over the 1980s and 1990s

${ }^{14}$ As opposed to the GNS classification, the BPM-5 classification does not include audiovisual services among communication services. In BOP trade statistics, audiovisual services are part of personal, cultural and recreational services.

${ }^{15}$ These observations apply also to other information-technology based services, such as computer and information services (see Table 6) and, in part, to "other business services (Table 8)
} 
Table 3. Exports of Communication Services.

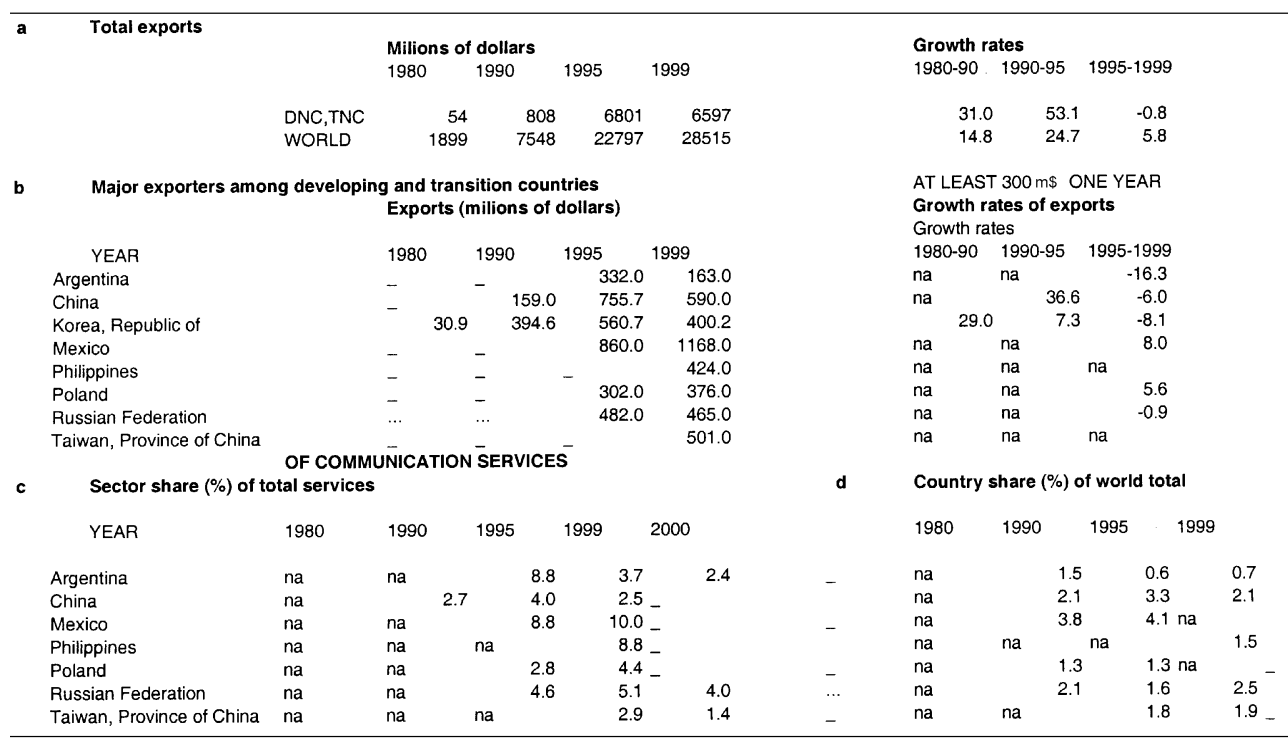

However, in the late 1990s developing and transition countries exporters appear to have fared poorly. The exception is constituted by Mexico, the only developing country with exports of communications services over US\$ 1 bn in 1999, after recording a strong $8 \%$ growth rate in 1995-1999.

BOP statistics on developing countries' exports of construction services are particularly poor (see table 4). This sector, almost by definition, is extremely important for most developing countries, but the overall presence of developing countries' in the international markets for construction services is scarce, in spite of the fact that the construction sector is not among the most technologically advanced. ${ }^{16}$ There are, however, two significant exceptions, Turkey and China, both of which with exports close to US\$ $1 \mathrm{bn}$ and world market shares over $3 \%$. It can be noted, moreover, that developing exporters of construction services as a whole appear to have recorded a very healthy growth rate also in the 1995-1999 period, while the world market actually shrank due mainly to the Asian crisis (Table 4a).

The brief observations on trade in construction services apply as well, a fortiori, to the statistics on trade in computer and information services (Table 5). Aggregate

\footnotetext{
${ }^{16}$ The bulk of the business for construction services is in the developing world, but most construction firms from developing countries have a hard time in achieving at least a minority share of their own domestic markets, let alone to attempt penetration in overseas markets.
} 
Table 4. Exports of Construction Services

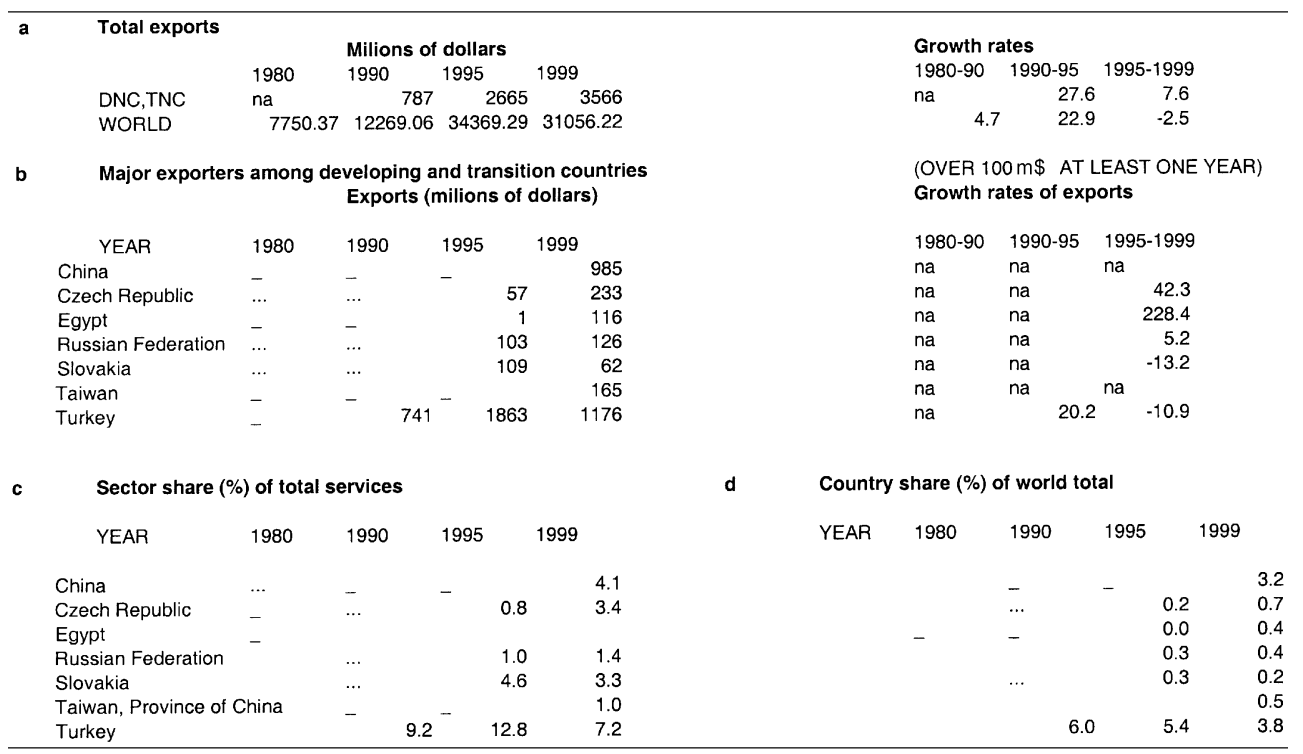

figures indicate that, starting from an almost zero base in the early 1980s, exports of this most modern, technology-based and dynamic services sector increased extremely fast over the last two decades, maintaining double-digit growth rates worldwide also in the late 1990s and reaching a total value of almost 30 US\$ bn in 1999. The role of developing countries in this play, however, is still marginal, in spite of recording overall growth rates higher than the world average (Table 5a). Data on single developing and transition country exporters of computer and information services are scant, although they indicate strong position of China and, to a lesser extent, Taiwan. ${ }^{17}$

Due to the peculiarities of the BOP sectoral classification, trade in several services activities in the domain of the computational and software industry is not recorded under the sectoral heading "computer and information services", but under the heading "other business services", which also covers many diverse services essential for trading, distribution, research and development, and other technical and professional activities.

The presence of developing countries in the international market for this

\footnotetext{
${ }^{17}$ The scarce (at least, according to global BOP statistics) presence of developing countries in international trade in this computer and information services is also caused by the simple fact that some developing countries, and notably India, record these exports under the heading "other business services" (see below).
} 
Table 5. Exports of Computer and Information Services.

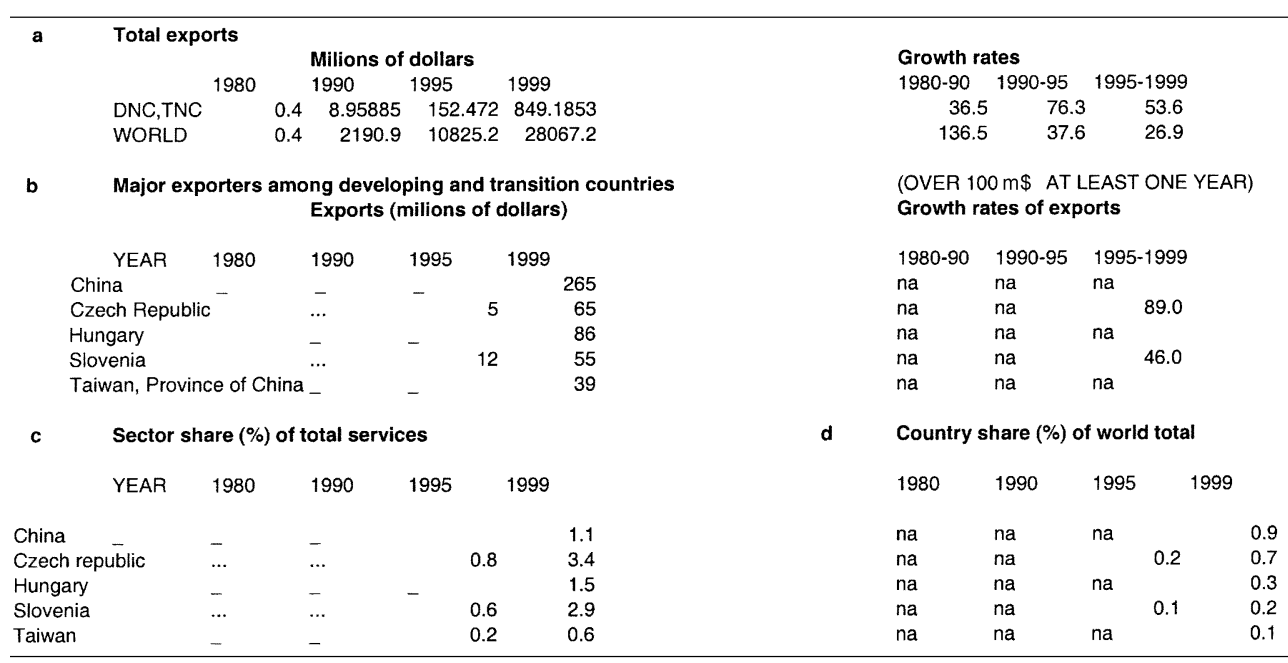

Table 6. Exports of Financial And Insurance Services.

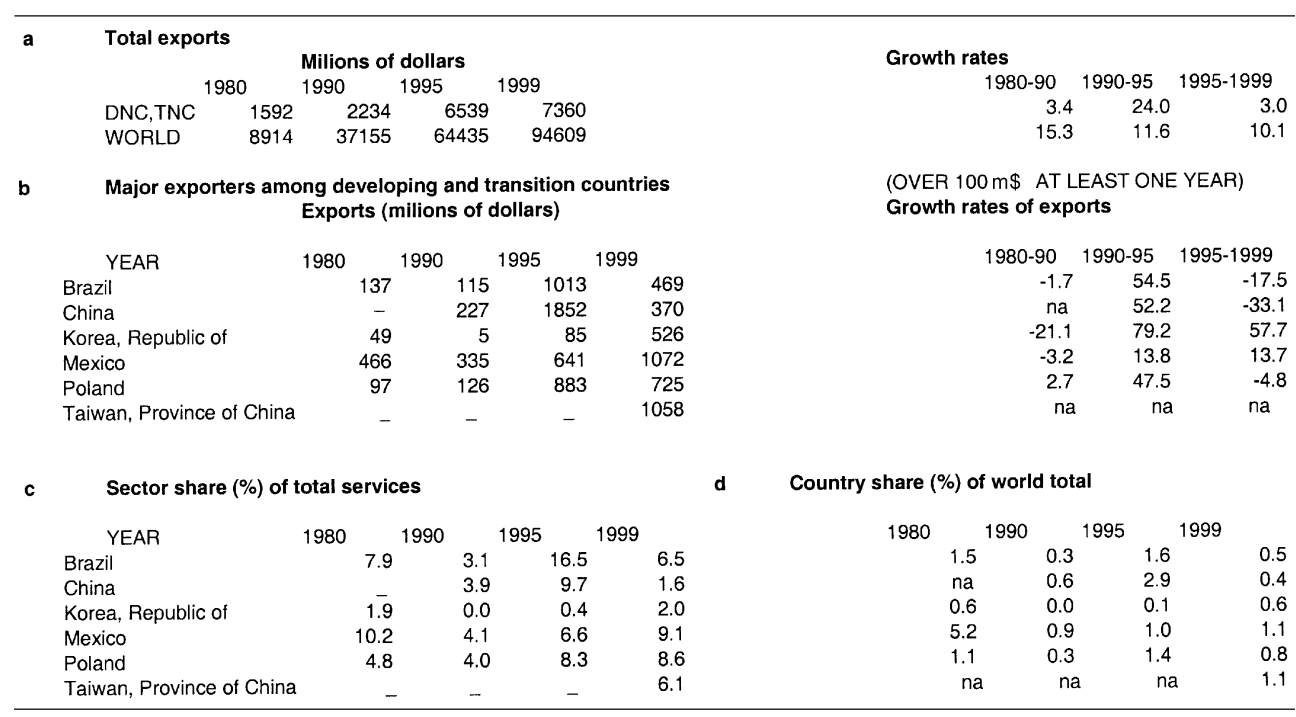

miscellaneous services is more relevant than in the cases of many other sectors. If the variously-classified software-related services were considered as a whole, actually, the presence of developing country exporters would be even more relevant: "....computer and data processing services are the industry with the highest share of developing country supply. In 1998, about $30 \%$ of US imports in this industry originated from developing countries, with India as the largest single supplier (Langhammer 2002, pp.304-305). 
Major developing players in the sector of "other business services" are all Asian, and many of them reached impressive levels of exports during the last decade (Table 7). Singapore recorded in 1995 exports receipts for US\$ $16.5 \mathrm{bn}$, the highest yearly export receipt for any single services sector recorded in a developing country over the whole 1980-1999 period, corresponding to almost $6 \%$ of the world market . During the subsequent period, characterized by the emergence of the regional financial crisis, Singapore's exports of "other business services" declined, as they did those of other two strong exporters, Korea and the Philippines (exports from the latter, which had reached almost US \$ 8bn, actually collapsed in 1995-1999). Conversely, exports of "other business services" from India, Malaysia, and Saudi Arabia increased also in the late 1990s (Table 7b, d). "Software exports have been India's most dynamic export sector" (Teltscher 2002, p.20): the Indian software industry, in fact, is probably the most well-known success story of a developing country exporting highly human capital intensive services (see Arora, Arunachalam(1999); OECD(2000); ILO(2001)). Software services exports from India grew at an extraordinary rate of over $40 \%$ per year rate in the late 1990 s,

Table 7. Exports of Other Business Services.

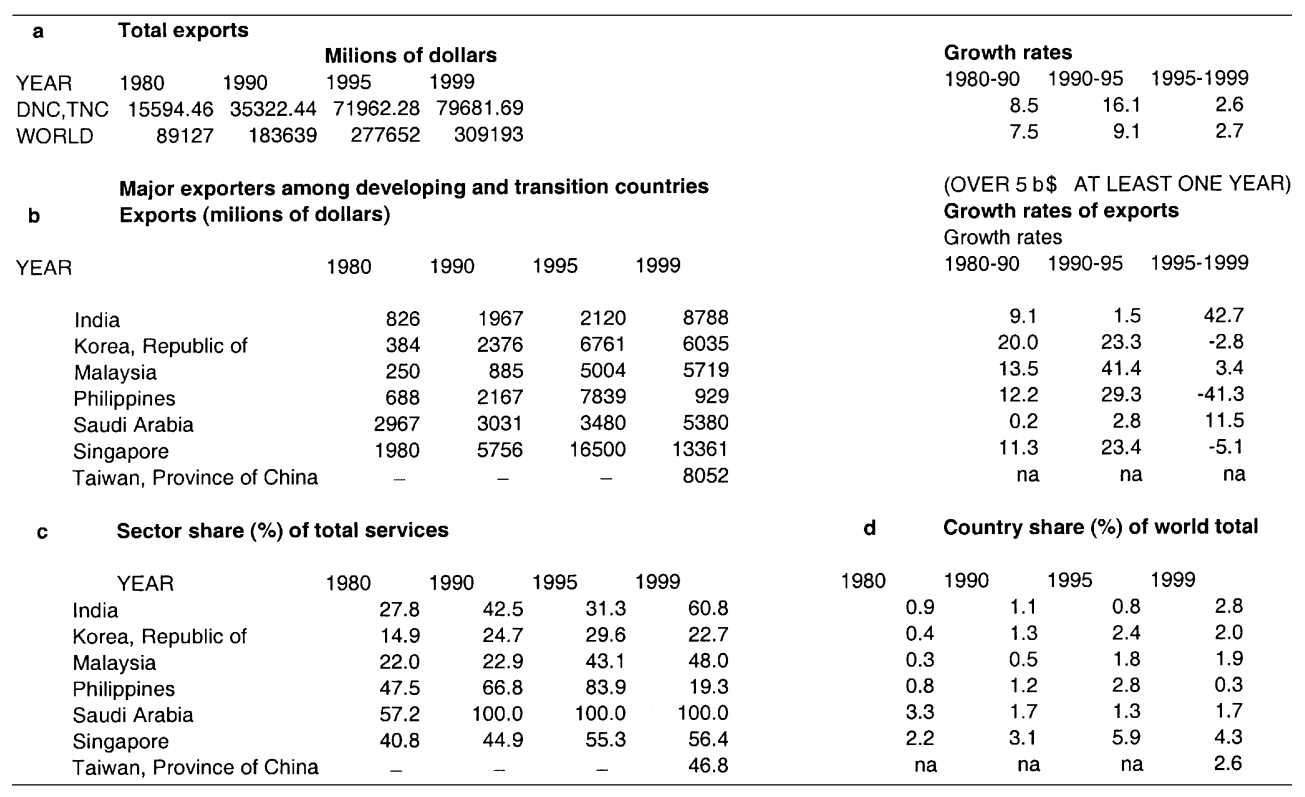

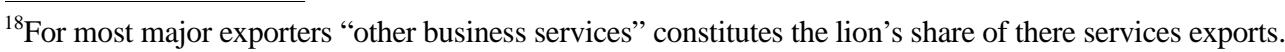
In the case of Saudi Arabia, exports of "other business services" are the totality of services exports (Table A7c).
} 
reaching over 8US\$ bn by the end of the decade (Table 7b), and they presently constitute a sizeable share of the country's total exports. ${ }^{19}$

Exports of financial and insurance services have being growing at more than $10 \%$ per year worldwide during the last 20 years, reaching a total volume of almost US $\$$ bn 100 by the end of the century. Developing countries, however, are minor players in international financial markets. Moreover, their exports of financial and insurance services almost stagnated in 1995-1999, severely eroding their share of world exports (Table 6a,d). Among major developing exporters, only Mexico in 1980 and China in 1995 achieved relatively high shares of world total exports, but they appear to have subsequently lost their positions ${ }^{20}$.

Exports of royalties and license fees (which include franchising) have been growing fast, both worldwide and in developing countries. However, the role of developing countries in the international markets for this services sector is still very minor (Table 8, 9). Major developing exporters include Asian and Latin American

Table 8. Exports of Royalties and License Fees

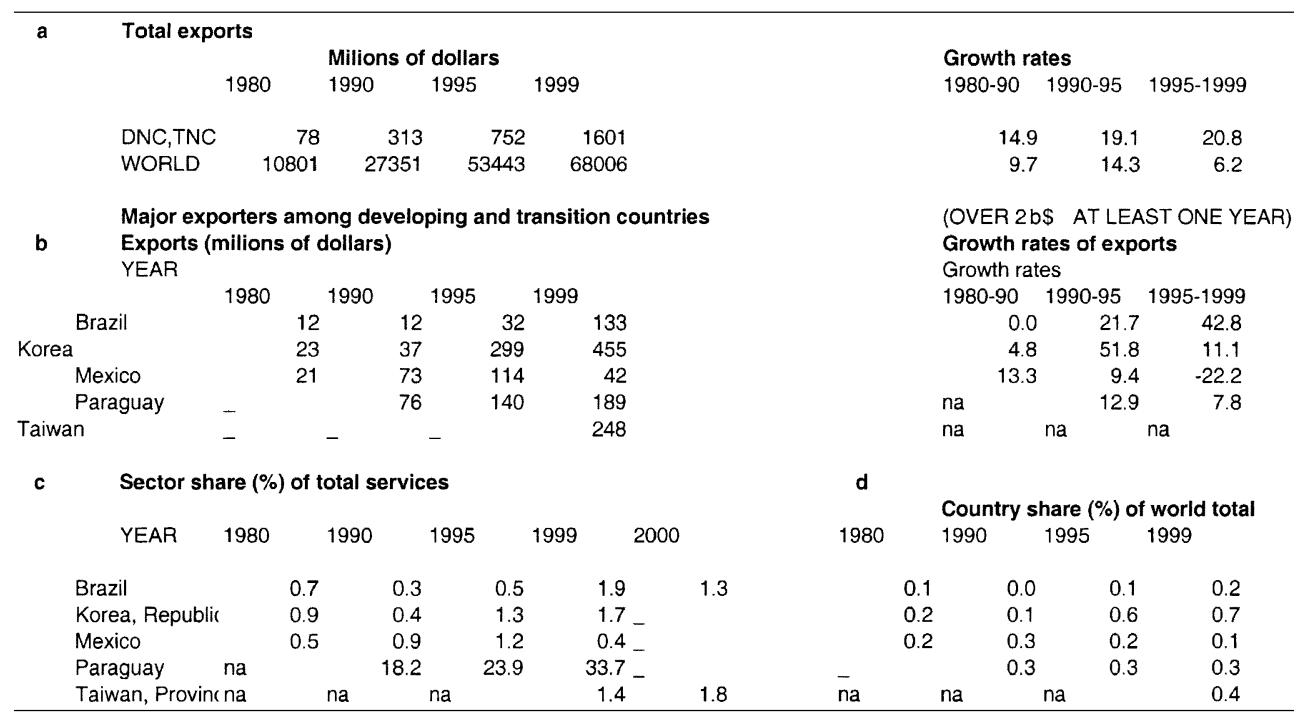

\footnotetext{
${ }^{19}$ According to a very updated estimate by NASSCOM-McKinsey (NASSCOM 2002, quoted in Teltscher 2002), by 2001-2002 software exports came to represent more than $16 \%$ of India's total exports. If the present trend will be confirmed in the near future, IT services exports from India will "reach US\$ 77 bn by 2008, contributing $10 \%$ to the country's GDP(up from 25 in 2002), $30 \%$ of all foreign exchange.. and creating four million new (direct and indirect) jobs." (Teltscher 2002, p.20)

${ }^{20}$ The dramatic fall of recorded exports of financial and insurance services from China between 1995 and 1999 is puzzling, and is likely to be imputable to statistical underreporting.
} 
Table 9. Exports of Personal, Computer and Recreational Services

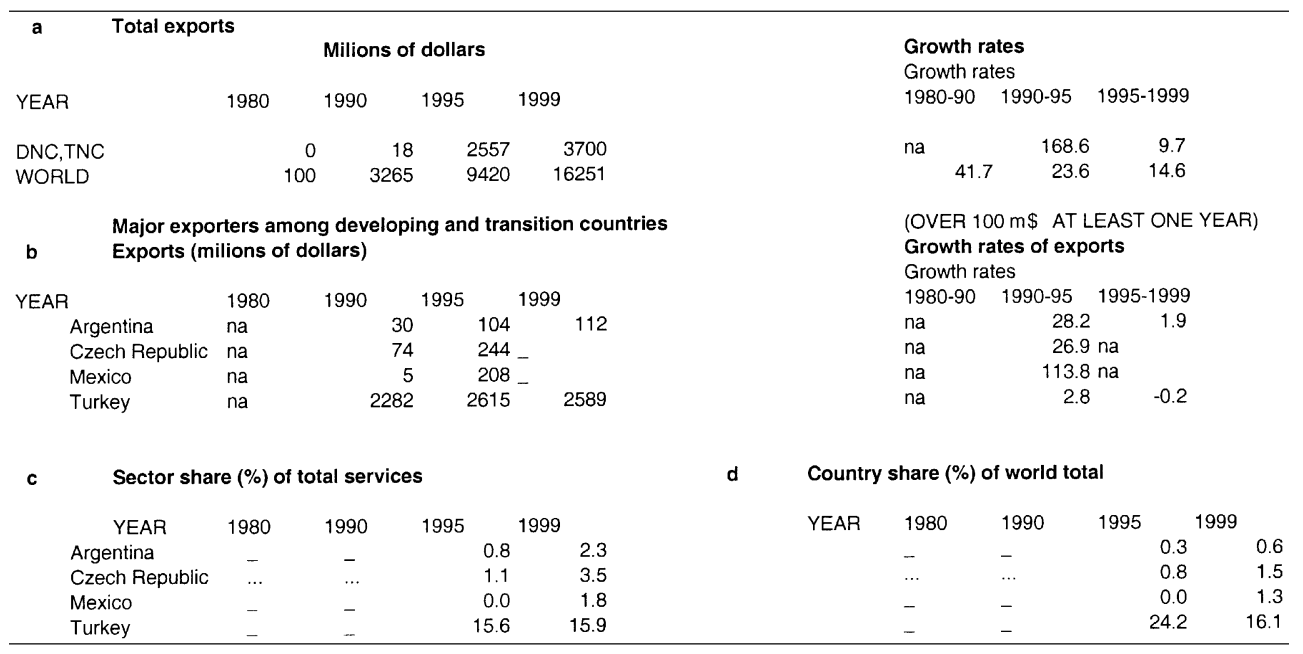

NICs and Paraguay. ${ }^{21}$

Exports of personal, cultural and recreational services, which include audiovisual services, have been growing quite strong both from developed and developing countries. In the latest 1995-1999 sub-period exports from developing and transitional countries still grew at an almost $10 \%$ annual rate, but this growth rate reversing the trend of 1990-1995 - was lower than the world average(Table 9). BOP data on exports of cultural and recreational services from developing countries show Turkey as the only sizeable player, with more than US\$ 2bn both in 1995 and 1999, and an extraordinary high two-digit share of the world market(Table 9b, d). However, it is apparent that available statistical information is particularly scant and inadequate in the case of personal, cultural and recreational services, and thus its informative contribution to evaluate the role of developing countries in the world market for this sector is likely to be limited ${ }^{22}$.

The last services sector, government services, has a peculiar nature, as government services are usually non-tradable. Exports of government services occur only

\footnotetext{
${ }^{21}$ Paraguay's strong position as an exporter in this services sector is due to the two hydroelectrical plants of Itaipu and Yasyreta.

${ }^{22}$ It is well-known, for instance, that several developing countries have developed a relatively strong indigenous base in some audiovisual sub-sectors, and their export performance might be not fully captured by available BOP statistics. In the case of India, for instance, a very large audiovisual industry is flourishing: although it is essentially geared towards the domestic markets, in recent years some audiovisual exports (targeting mainly, but not exclusively, the large overseas Indian community) have being take place, but they might not be adequately captured by BOP statistics.
} 
Table 10. Exports of Government Services

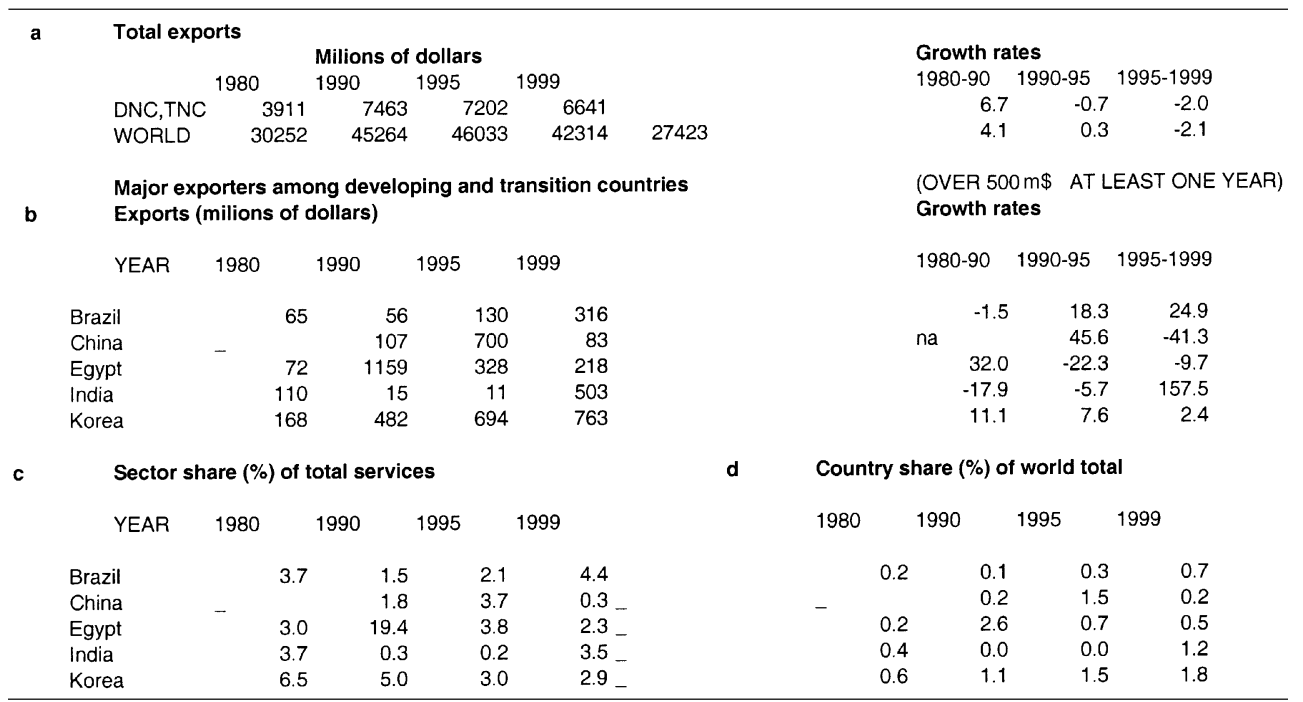

under particular circumstances, usually in the framework of intergovernmental bilateral or regional agreements. As this sector is intrinsically different from market-oriented commercial services proper, it is not surprising that exports of government services grew slowly in the 1980s and stagnated or declined in the 1990s (Table 10). The role of developing countries in exports of government services is not very relevant (Table 10a). Major developing exporters are Korea, India, Brazil, Egypt, and China (Table 10b).

\section{An Overview of International Trade in Services}

Tables 11-13 present data on total trade flows in services for various groups of countries. Table 11 refers to exports of total services, Table 12 to imports, and Table 13 to the balance of trade in services. Tables 11-13 show the values of total services exports, imports, and trade balances, exports in millions of (current) US dollars, the corresponding shares of world total, and the growth rates of exports and imports for three different periods ${ }^{23}$ (1980-1990; 1990-1995;1995-2000).

\footnotetext{
${ }^{23} \mathrm{As}$ in this table, as in all other tables, growth rates refer to services export in current US \$, they overestimate the real growth rates by an amount equal to international inflation.
} 
Table 11. Exports of Services

\begin{tabular}{|c|c|c|c|c|c|c|c|c|}
\hline & \multicolumn{2}{|c|}{ Total Exports } & \multicolumn{2}{|c|}{ Millions of dollars } & \multicolumn{3}{|c|}{ Growth rates } & \multirow[b]{2}{*}{ 1995-2000 } \\
\hline YEAR & $1980 \quad 1$ & 1990 & $1995 \quad 2$ & 2000 & $1980-90 \quad 1$ & $1990-20001$ & 1990-95 & \\
\hline \multicolumn{9}{|l|}{ COUNTRY/GROUP } \\
\hline World & 336855.2 & 780408.8 & 1168717 & 1427632 & 8.764682 & 6.225652 & 8.412017 & 4.08337892 \\
\hline Developed countries & 276234 & 623379 & 864037 & 1033042 & 8.5 & 5.2 & 6.7 & 3.6 \\
\hline Developing countries & 56319 & 147111 & 260813 & 346827 & 10.1 & 9.0 & 12.1 & 5.9 \\
\hline Developing countries: America & 17114 & 29043 & 42906 & 56773 & 5.4 & 6.9 & 8.1 & 5.8 \\
\hline Developing countries: Africa & 9474 & 15101 & 20960 & 29144 & 4.8 & 6.8 & 6.8 & 6.8 \\
\hline Developing countries: Asia & 24501 & 95170 & 190435 & 252732 & 14.5 & 10.3 & 14.9 & 5.8 \\
\hline Developing countries: Oceania & 247 & 702 & 1014 & 917 & 11.0 & 2.7 & 7.6 & -2.0 \\
\hline Developing countries: Europe & 4982 & 7095 & 5497 & 7260 & 3.6 & 0.2 & -5.0 & 5.7 \\
\hline Major petroleum exporters & 10894 & 14691 & 16629 & 32980 & 3.0 & 8.4 & 2.5 & 14.7 \\
\hline Major exporters of manufactures & 20315 & 89136 & 183236 & 234381 & 15.9 & 10.2 & 15.5 & 5.0 \\
\hline High income countries & 23182 & 72619 & 137574 & 176840 & 12.1 & 9.3 & 13.6 & 5.1 \\
\hline Middle income countries & 20073 & 50314 & 88049 & 110373 & 9.6 & 8.2 & 11.8 & 4.6 \\
\hline Low income countries & 8523 & 17804 & 35190 & 59615 & 7.6 & 12.8 & 14.6 & 11.1 \\
\hline Least developed countries & 2160 & 3038 & 5143 & 5728 & 3.5 & 6.5 & 11.1 & 2.2 \\
\hline Heavily indebted poor countries & 3428 & 4248 & 5674 & 7143 & 2.2 & 5.3 & 6.0 & 4.7 \\
\hline \multirow[t]{3}{*}{ Land-locked countries } & 1006 & 1952 & 3841 & 6246 & 6.9 & 12.3 & 14.5 & 10.2 \\
\hline & \multicolumn{4}{|c|}{ Share $(\%)$ of world total } & & \multicolumn{3}{|c|}{ Share $(\%)$ of total trade } \\
\hline & $1980 \quad 1$ & $1990 \quad 1$ & 1995 & 2000 & 1980 & 1990 & 1995 & 2000 \\
\hline World & na & na & na & na & 14.22 & 18.29 & 18.56 & 18.41 \\
\hline Developed countries & 0.82 & 0.80 & 0.74 & 0.72 & 17.57 & 20.03 & 19.72 & 20.36 \\
\hline Developing countries & 0.17 & 0.19 & 0.22 & 0.24 & 8.83 & 14.99 & 15.46 & 14.58 \\
\hline Developing countries: America & 0.05 & 0.04 & 0.04 & 0.04 & 13.28 & 16.71 & 16.00 & 14.16 \\
\hline Developing countries: Africa & 0.03 & 0.02 & 0.02 & 0.02 & 9.17 & 15.56 & 20.38 & 20.53 \\
\hline Developing countries: Asia & 0.07 & 0.12 & 0.16 & 0.18 & 6.30 & 13.90 & 14.80 & 14.01 \\
\hline Developing countries: Oceania & 0.00 & 0.00 & 0.00 & 0.00 & 9.67 & 20.02 & 17.90 & 19.04 \\
\hline Developing countries: Europe & 0.01 & 0.01 & 0.00 & 0.01 & 34.50 & 31.49 & 23.75 & 26.81 \\
\hline Major petroleum exporters & 0.03 & 0.02 & 0.01 & 0.02 & 3.35 & 6.35 & 6.59 & 7.62 \\
\hline Major exporters of manufactures & 0.06 & 0.11 & 0.16 & 0.16 & 10.71 & 15.32 & 15.44 & 14.31 \\
\hline High income countries & 0.07 & 0.09 & 0.12 & 0.12 & 6.55 & 13.48 & 14.20 & 13.93 \\
\hline Middle income countries & 0.06 & 0.06 & 0.08 & 0.08 & 11.09 & 18.42 & 20.31 & 16.82 \\
\hline Low income countries & 0.03 & 0.02 & 0.03 & 0.04 & 9.50 & 11.95 & 12.39 & 13.16 \\
\hline Least developed countries & 0.01 & 0.00 & 0.00 & 0.00 & 12.86 & 15.64 & 19.03 & 15.38 \\
\hline Heavily indebted poor countries & 0.01 & 0.01 & 0.00 & 0.01 & 12.72 & 13.88 & 13.78 & 11.95 \\
\hline Land-locked countries & 0.00 & 0.00 & 0.00 & 0.00 & 10.71 & 15.39 & 13.33 & 16.49 \\
\hline $\begin{array}{l}\text { is slightly less than } 1 \text { becaus } \\
\text { (Countries in Eastern Europ }\end{array}$ & are report & eparate & the & $\begin{array}{l}\text { thy gro } \\
\text { AD dat }\end{array}$ & & & & \\
\hline
\end{tabular}

\section{A. Total exports of services}

International trade in exports worldwide has been expanding rapidly in the last decades of the XX century, growing on average faster than both the world GNP and world merchandise trade ${ }^{24}$. In absolute terms, total exports of services more than quadrupled between 1980 and 2000, growing from 337billion US \$ to 1.4 trillions. However, this expansion took place at a decreasing pace, with the rate of growth slowing down in the 1990 in respect of the trend prevailing in the 1980s, due essentially to an abrupt deceleration that took place in the second half of the decade. This slowdown would be less pronounced if measured in real terms (as the yearly US GDP deflator decreased, on average, from 3.8 per cent in 1980-1990 to 2.1 per cent in $1990-1999^{25}$ ), but it would not disappear altogether. Therefore, it

${ }^{24}$ During the 1990s, however, merchandise and services exports expanded at roughly the same pace.

${ }^{25}$ Source: World Bank, WDI 2001. 
must be acknowledged that a deceleration in international trade in services did occur, especially in the late 1990s, along with the global deceleration of the world economy ${ }^{26}$.

In table 11, in order to focus first and foremost on the divide between developed countries and the rest of the world, all countries were classified into two large groupings: "Developed countries" (DDCs) and "Developing countries"27 (DNCs). Growth in total exports of services, starting from a much lower basis, has been faster on average in developing countries than in developed countries in all the three sub-periods, allowing the former to capture an increasing share of world trade. It is also noticeable that, contrarily to what happened in the developed countries, growth in services exports from developing countries actually accelerated in the early 1990s. However, in the latest period, the growth rate of total exports of services roughly halved both in developed (from 6.7\% in 1990-1995 to 3.6\% in 1995-2000) and in developing countries (from $12.1 \%$ to $5.9 \%$ ). These broad statistical trends are consistent with Langhammer's skeptical view: "Measured both in terms of growth and shares, world trade in commercial services has not risen spectacularly... in 1998 merchandise trade still comprised four fifths of world total trade...For developing countries, the contribution of service exports to their total trade was even declining... ${ }^{28 "}$ (Langhammer, 2002: 297-298). In fact, the most recent available data show that by the year 2000 the share of services in developing countries' total exports had actually declined to $14.6 \%$, lower than the correspondent figure in $1995(15.5 \%)$ and even than in $1990(15 \%)$.

Among regional groups, there are important differences, although the decelerating

\footnotetext{
${ }^{26}$ The deceleration of international trade in services took place in correspondence to the quasi-universal - albeit progressive and still partial - implementation of the new GATS regime. Such a disappointing trend, so far, appears to run counter the over-optimistic expectations pinned by many analysts on the growth-enhancing potential of the liberalization of multilateral rules on trade in services.

${ }^{27}$ Country groupings in Table 1 follow the UNCTAD database classification. According to this classification, the group "Developing countries" is constituted by developing countries in America, Africa, Asia, and Oceania, plus a fifth sub-group, "European developing countries", constituted by Malta and by some republics formerly belonging to Yugoslavia. The remaining formerly socialist European countries are classified in the UNCTAD database as belonging to a sixth sub-group, "Countries in Eastern Europe". Long-term series on trade in services in transition economies, and especially in the latter sub-group (which is fact residual) are not consistent and historically comparable, due largely to the limited availability on trade in services in the former USSR. Therefore, data on the residual sub-group "Countries in Eastern Europe" are not presented in Table 1. Consistently, the sum of data referring to developed and developing countries is less than the world total.

${ }^{28}$ Langhammer refers to the $1989-1998$ period.
} 


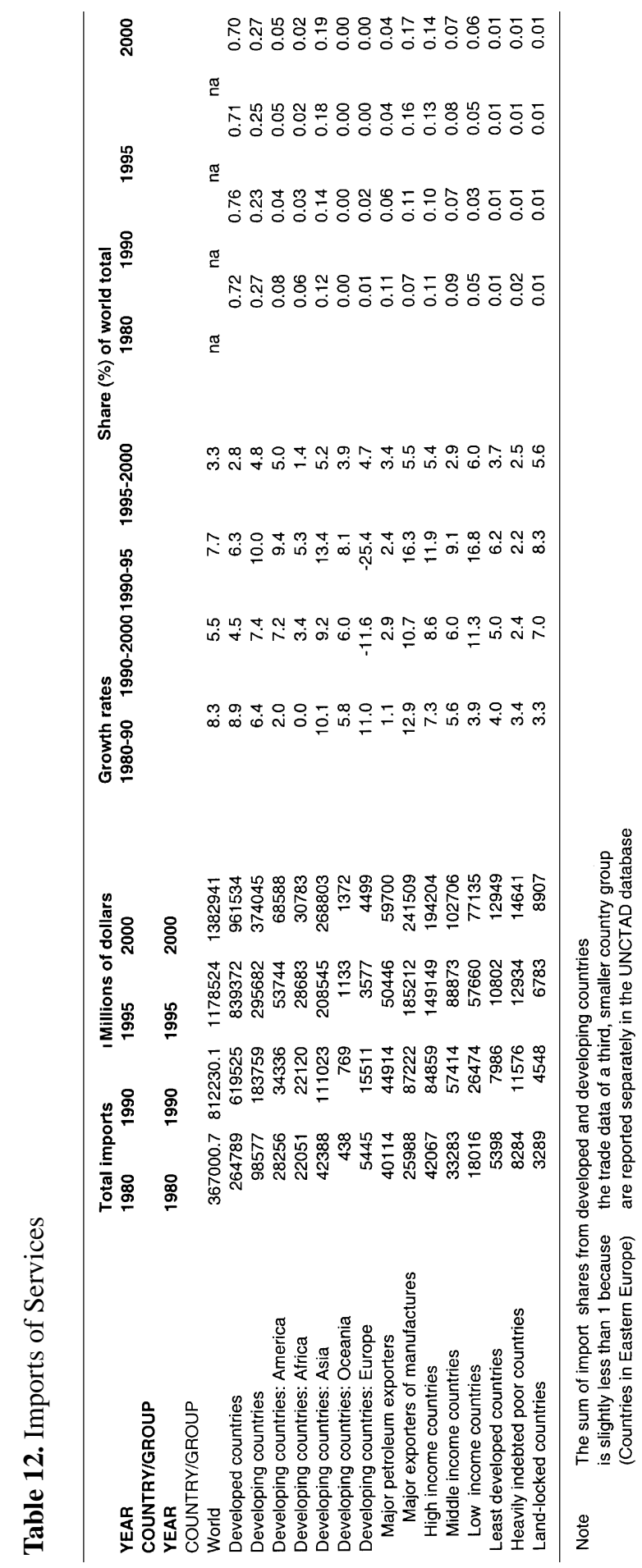


trend is common to all developing countries. Exports of services from American DNCs grew less than the world average in the still-dynamic 1980s and, marginally, in the early 1990s. As a result, even with a modest relative recuperation in the slow-growing late 1990s, their share of world services exports was lower in 2000 (4\%) than in 1980 (5.1\%). The relative weight of services in Latin American total exports also declined, and by 2000 it was 2.5 percentage points lower than in 1990 .

African DNCs, on the contrary, which had experienced a below-average services export performance during the 1980s, were the only regional group that managed to accelerate the dynamism of its services exports over the 1990s. As a result, Africa's share of total world services export increased slightly, although it remained very low ( $2 \%$ by the year 2000). It is also interesting to note that Africa is the only developing region where the relative role of services in total exports kept increasing during the 1990s: as result, by the year 2000, the share of services in total exports in Africa was $20.5 \%$, the highest among developing regions ${ }^{29}$ and higher even than the average for developed countries.

Asian DNCs expanded services exports at an over $14 \%$ yearly rate up to the mid1990s, but their performance slowed down markedly in 1995-2000 (less than 6\% per year on average). In spite of this marked slow-down, Asia's share of world total services exports in 2000 was $18 \%$, equivalent to more than twice the correspondent figure for 1980 and to $2 / 3$ of total services exports from developing countries. ${ }^{30}$

Trends in the remaining two regional groups cannot be interpreted along the same lines. The group of Oceanian DNCs is just too small to allow for any generalization beyond the specific cases of each individual country. The group of European DNCs is essentially formed by semi-industrialized former socialist countries, and therefore the severe drop in services exports recorded in the early 1990s is to be seen in the framework of the overall collapse of their economy. That collapse eventually gave place to a modest recovery, which barely allowed services exports to regain the nominal (absolute) level of 1990 by the end of the decade. ${ }^{31}$

\footnotetext{
${ }^{29}$ The share of services in total export is higher in "developing Europe", but this region actually covers some formerly socialist, relatively industrialized transition countries (see note 13).

${ }^{30}$ A comparison between Asia's and Latin America's shares of world total services exports is particularly telling. The ratio between the two only about was less $1.5 / 1$ in 1980 , but it rose to more than $4 / 1$ in 2000 .

${ }^{31}$ Historical data series on trade in services in European developing countries suffer, to some extent, of the same limitations of trade data referring to "countries in Eastern Europe", and therefore are to be interpreted in a purely indicative fashion (see note 13).
} 
Focusing on two prominent groups of DNCs - major oil and manufacture exporters - it can be seen that up to the mid-1990s the former were losing ground (in relative terms ) as services exporters, while the latter were expanding at a very fast pace. More recently, however, under the impact ( among other factors) of increases in oil prices and of the Asian crisis - this trend has been reversed, at least temporarily. Grouping developing countries according to income, growth rates of services exports appear to be common to all of them up to the mid 1990s. However, in the 1995-2000 period only low income countries maintained growth rates over $10 \%$, while both middle income and low income countries experienced a marked deceleration. The fact that the relative performance of low income countries with respect to other DNCs has been improving over time, and since 1990 it has been better than both the world and the DNC average, can be considered mildly encouraging. However, this trend does not apply to all low income countries. If we look specifically to the performance of three specific groups of particularly disadvantaged countries (LDCs, heavily indebted poor countries, and land-locked countries) ${ }^{32}$, it is apparent that the only one to exhibit satisfactory results is the group of land-locked countries. LDCs and heavily indebted poor countries, on the contrary, saw their already meager share of world trade in service shrink progressively over the 1980-2000 period..$^{33}$

Disaggregated data on the ten services sectors (see the Annex and the Annex tables) show that major developing exporters of services largely coincide with major developing exporters of goods. Yet, the overlapping is not complete: some developing countries with relatively modest merchandise export performances appear to specialize rather successfully in exporting certain kinds of services - this is the case, for instance, of Turkey, Egypt, Paraguay ${ }^{34}$. It is also apparent that, with some interesting exceptions, exporters from developing countries are relatively stronger in traditional, slow-growing services markets:

"The modest performance of developing countries as exporters of services fits in the

\footnotetext{
${ }^{32}$ Some countries belong to more than one of these sub-groups.

${ }^{33}$ To some extent, this result is a truism, as the groups of LDCs and heavily indebted poor countries are, by definition, composed by poor countries which are severely strained both economically and financially. Conversely, if a country performs well, it will eventually lose the dubious privilege of belonging to these groups. Land-lockedness, on the contrary, is a permanent and non-modifiable feature which can constitute a relative, but not an absolute constraint to development.

${ }^{34} \mathrm{~A}$ more detailed assessment of the major developing and transition countries exporters' performance in the ten services sectors is presented in the Annex and in the Annex tables.
} 
broad sectoral pattern of service exports. During the nineties, the share of traditional service exports (such as travel and transport) in total commercial services declined while that of so-called other commercial services (often referred to as producer services) rose sharply... This is not surprising since it is in human capital intensive producer services (financial services, communication services, and marketing services) where developed countries are expected to enjoy comparative advantages and where the emergence of new markets has been benefited from technological innovations originating from and introduced in developed countries (Langhammer 2002, pp. 298-299).”

\section{B. Total imports of services}

Due in part to the limited accuracy of statistical data (see below, comments on Table 13), trends in international imports of services by very large groups of countries broadly mirror those in services exports, but appear to exacerbate the already observed declining trend in growth rates. In the last sub-period (19952000), in particular, recorded imports of services worldwide grew by only $3.3 \%$ per year, less than one half the growth rate of the preceding sub-period, which had already exhibited a deceleration with respect to the 1980s. This deceleration appears to have been due mainly to a large drop in developed countries' services imports (from 6.3\% per year on average in 1990-1995 to $2.8 \%$ per year in 1995-

Table 13. Balance of Trade In Services (Millions of Dollars).

\begin{tabular}{lrrrr}
\hline YEAR & 1980 & 1990 & 1995 & 2000 \\
COUNTRY/GROUP & & & & \\
YEAR & & & & \\
COUNTRY/GROUP & -30145.6 & -31821.3 & -9806.86 & 44690.41 \\
World & 11444 & 3854 & 24665 & 71508 \\
Developed countries & -42258 & -36648 & -34869 & -27218 \\
Developing countries & -11141 & -5293 & -10838 & -11815 \\
Developing countries: America & -12577 & -7019 & -7723 & -1639 \\
Developing countries: Africa & -17886 & -15853 & -18110 & -16070 \\
Developing countries: Asia & -191 & -67 & -119 & -455 \\
Developing countries: Oceania & 5449 & -821 & 13053 & 28481 \\
Developing countries: Europe & -19799 & 44222 & 132790 & 174682 \\
$\quad$ Major petroleum exporters & -2806 & -14602 & -47638 & -64669 \\
$\quad$ Major exporters of manufactures & -21994 & -34545 & -61100 & -83832 \\
$\quad$ High income countries & -24760 & -39610 & -53683 & -43091 \\
$\quad$ Middle income countries & -15857 & -23436 & -52517 & -71406 \\
$\quad$ Low income countries & -1971 & -3738 & -5127 & -5805 \\
tative & -7278 & -9624 & -9093 & -8394 \\
Heavily indebted poor countries & -3289 & -4548 & -6783 & -8907 \\
\hline Land-locked countries & & & & \\
\hline
\end{tabular}


2000), but the correspondent decrease for developing countries (from $10 \%$ to $4.8 \%$ per year) was also steeper than in the case of imports. As the deceleration was sharper in the North, the share of developing countries in total world imports of services increased moderately during the 1990s and by the year 2000 it was back to its 1980 level (27\%).

Although possibly magnified by statistical imperfections, these figures indicate a significant decline in developing countries' ability to import services - many of which are absolutely necessary to sustain any kind of growth or developing path in the contemporary, increasingly globalizing world economy. The deteriorating trends are common to all developing country sub-groups ${ }^{35}$ - although low income and land-locked countries fared someway better than others - but are particularly pronounced in the case of Africa, in contrast with this region's relatively positive performance on the side of services exports.

\section{Balance of trade in services}

The above-mentioned imperfections of available statistical information are made apparent by the large gap between world exports and imports of services, which appears to show a "positive" trend in the balance of trade in services for the whole world, which shifts from a deficit (up to 1995) to a surplus position (in 2000). With this caveat, Table 1c also shows a continuous decline in developing countries' services balance, which fell from US42bn in 1980 to US\$36bn in 1990 and to US\$ $27 \mathrm{bn}$ in 2000. This decline is almost exclusively the product of the quasidisappearance of the services deficit in Africa (from over 12USbn in 1980 to less than US2bn in 2000).

Because its economic structure is the least diversified and articulated, Africa, among all world regions, is the one most dependent on services (and goods) imports, while at the same time is also the least capable to finance such imports with its own resources. Bearing this in mine, the development implications of the trend mentioned above are far from encouraging.

More broadly, for developing countries as a whole, the sign of these figures (if not the magnitude) probably reflects a true and important phenomenon that is still poorly understood in its entirety and implications, but is likely to be related to the draconian structural adjustment policies carried out in the 1980s and 1990s.

\footnotetext{
${ }^{35}$ The only sub-group to record an increase in the growth rate of services imports between 1990-1995 and 1995-2000 is that of the European developing countries, many of which were plunged in war during the early 1990s.
} 


\section{Conclusions}

Most of the main exporters in each of the services sub-sectors among developing and transition countries belong to two groups. One is constituted by large semiindustrialized Asian countries, that exhibited a strong overall growth and export performance over the last two decades. The other is formed by countries in Eastern Europe which, in spite of the severe crisis they have been through, maintained a relatively high level of industrial and technological development. Yet, there are also cases of other developing countries that show a strong tendency to specialize in one or few specific services sub-sectors.

During the last two decades of the XX century, the share of the developing countries in total world services exports increased progressively, reaching almost 1/ 4 of the world total in 2000. However, developing countries did not escape from a generalized slow-down in international trade in services. The growth rate of services exports from developing countries halved in 1995-2000 with respect to first half of the decade, largely due to the impact of the Asian crisis. Developing countries' ability to import services also declined sharply, with serious consequences on their overall economic performances.

A tentative explanation is as follows. Although important exceptions do exist, and tend to become progressively more significant and widespread, outwardoriented services activities in developing countries are still mostly confined to the less advanced services sectors and poorly integrated with the rest of the domestic economy. Moreover, they are often under the control of foreign enterprises and operators. During the late 1990s, indebtness and crisis conditions, and the difficulty to obtain access to multilateral development financing, contributed to increase in many developing countries the urgency to cut imports and boost exports (even at the cost of sacrificing present and future growth perspectives) and to actively court foreign investors. The impact of these policies was also felt by services, where imports were sacrificed and exports further encouraged. TNCs also extended their commercial presence throughout the developing world, often according priority to foreign exchange generating services (i.e., in the travel sector, which includes tourism $)^{36}$. In the worst cases, this policy bias caused a further deterioration of the

\footnotetext{
${ }^{36}$ Due to the inadequacies in statistics on international trade in services, it is not possible to disentangle systematically which share of services exports actually accrued to developing countries' enterprises, and to which extent the change in developing countries' balance of services actually reflects a true increase in international competitiveness.
} 
terms of trade and a deepening of the traditional disarticulation of export-oriented activities from the bulk of the domestic economy.

Trade and financial liberalization policies aimed at accelerating developing countries' trade and financial integration in the world economy, in order to reap fully the benefits of globalization. However, in many developing countries, they were carried out in an unbalanced and hasty fashion. Due to the lack of policy focus, a higher degree of external integration did not translate in an overall technological upgrading and in an improvement in the countries' relative position in worldwide trade flows. As a consequence, the ultimate economic results were less than satisfactory.

Received 30 October 2002, Accepted 5 May 2003

\section{References}

Arora A., Arunachalam V.S.(1999), The Indian Software Services industry, Carnegie Mellon University Heinz School Working Paper 1999-19, Pittsburg, PA, December. ILO (International Labour Organization), 2001, Life at Work in the Information Economy, World Employment Report 2001, Geneva.

Langhammer R.J., 2002, Developing Countries as Exporters of Services: What Trade Statistics Suggest, Journal of Economic Integration, 17(2): 297-310.

NASSCOM (National Association of Software and Services Companies), 2002, Software

Exports. See www.nasscom.org/it_industry/SW_export.asp.

OECD 2000, Information Technology Outlook: ICTs, E-commerce and the Information Economy, OECD, Paris.

Teltscher S., 2002, Export Competitiveness and E-Services, UNCTAD, Geneva (mimeo). WTO (1997), A review of statistics on trade flows in services - Note by the Secretariat, (S/ $\mathrm{C} / \mathrm{W} / 27)$, Geneva.

WTO (2000), A review of statistics on trade flows in services - Note by the Secretariat Addendum, (S/C/W/27/Add.1), Geneva. 